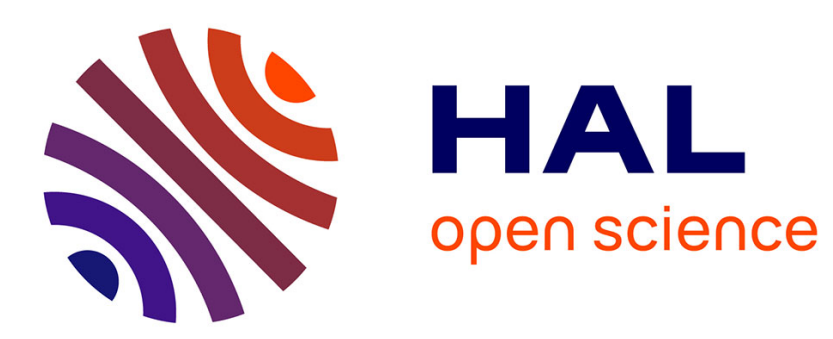

\title{
Functional expression of SLC15 peptide transporters in rat thyroid follicular cells
}

\author{
A. Romano, A. Barca, G. Kottra, H. Daniel, C. Storelli, T. Verri
}

\section{To cite this version:}

A. Romano, A. Barca, G. Kottra, H. Daniel, C. Storelli, et al.. Functional expression of SLC15 peptide transporters in rat thyroid follicular cells. Molecular and Cellular Endocrinology, 2009, 315 (1-2), pp.174. 10.1016/j.mce.2009.11.002 . hal-00547663

\section{HAL Id: hal-00547663 https://hal.science/hal-00547663}

Submitted on 17 Dec 2010

HAL is a multi-disciplinary open access archive for the deposit and dissemination of scientific research documents, whether they are published or not. The documents may come from teaching and research institutions in France or abroad, or from public or private research centers.
L'archive ouverte pluridisciplinaire HAL, est destinée au dépôt et à la diffusion de documents scientifiques de niveau recherche, publiés ou non, émanant des établissements d'enseignement et de recherche français ou étrangers, des laboratoires publics ou privés. 


\section{Accepted Manuscript}

Title: Functional expression of SLC15 peptide transporters in rat thyroid follicular cells

Authors: A. Romano, A. Barca, G. Kottra, H. Daniel, C.

Storelli, T. Verri

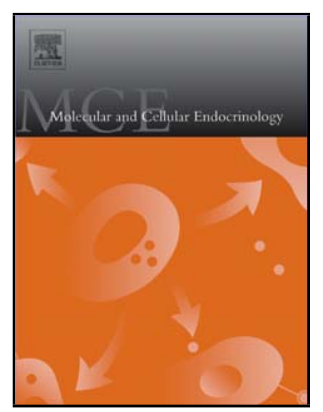

PII:

S0303-7207(09)00567-X

DOI: doi:10.1016/j.mce.2009.11.002

Reference: MCE 7366

To appear in: $\quad$ Molecular and Cellular Endocrinology

Received date: $\quad$ 4-6-2009

Revised date: 23-9-2009

Accepted date: $\quad$ 2-11-2009

Please cite this article as: Romano, A., Barca, A., Kottra, G., Daniel, H., Storelli, C., Verri, T., Functional expression of SLC15 peptide transporters in rat thyroid follicular cells, Molecular and Cellular Endocrinology (2008), doi:10.1016/j.mce.2009.11.002

This is a PDF file of an unedited manuscript that has been accepted for publication. As a service to our customers we are providing this early version of the manuscript. The manuscript will undergo copyediting, typesetting, and review of the resulting proof before it is published in its final form. Please note that during the production process errors may be discovered which could affect the content, and all legal disclaimers that apply to the journal pertain. 


\title{
Functional expression of SLC15 peptide transporters in rat thyroid follicular cells
}

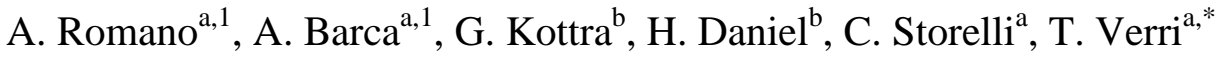

${ }^{a}$ Laboratory of General Physiology, Department of Biological and Environmental Sciences and Technologies, University of Salento, via Provinciale Lecce-Monteroni, I-73100 Lecce, Italy

${ }^{\mathrm{b}}$ Molecular Nutrition Unit, Nutrition and Food Research Center, Technical University of Munich, Am Forum 5, D-85350 Freising-Weihenstephan, Germany.

\section{Footnotes}

Abbreviations: Ala-Lys-AMCA, $\beta$-Ala-Lys- $\mathrm{N}_{\varepsilon}-7$-amino-4-methyl-coumarin-3-acetic acid; carnosine, $\beta$-alanyl-L-histidine; PC Cl3 cells, PC cell line clone 3; SLC15, SoLute Carrier 15; $\mathrm{Tg}$, thyroglobulin.

${ }^{1}$ These authors equally contributed to this work.

*Corresponding author: Tiziano Verri, Laboratory of General Physiology, Department of Biological and Environmental Sciences and Technologies, University of Salento, via Provinciale Lecce-Monteroni, I-73100 Lecce, Italy; Tel: (39) 0832 298869; Fax: (39) 0832 324220. E-mail address: tiziano.verri@unisalento.it 


\begin{abstract}
Peptide transport and expression of SoLute Carrier 15 (SLC15) peptide transporters was assessed in rat thyroid tissue and a rat thyroid cell line (PC Cl3 cells). Peptide transport was studied by monitoring the uptake of the fluorophore-conjugated dipeptide $\beta$-Ala-Lys- $\mathrm{N}_{\varepsilon^{-}} 7$ amino-4-methyl-coumarin-3-acetic acid (Ala-Lys-AMCA). Expression of SLC15-specific mRNA transcripts was analyzed by RT-PCR. Of the two SLC15 transporters expressed in thyroid follicular cells, namely PEPT2 (SLC15A2) and PHT1 (SLC15A4), only PEPT2 was involved in peptide transport at the plasma membrane, with PHT1 most likely being intracellular. Interestingly, at the mRNA level PEPT2 was up-regulated under TSH stimulation. These findings represent the first evidence that peptide transport occurs in thyroid follicular cells. SLC15 transporters could participate to recycling of peptides derived from extracellular and lysosomal thyroglobulin proteolysis, both essential steps for thyroid hormone synthesis.
\end{abstract}

\title{
Keywords
}

$\beta$-Ala-Lys- $\mathrm{N}_{\varepsilon^{-}}$-amino-4-methyl-coumarin-3-acetic acid; PC Cl3 cells; SoLute Carrier 15 family; thyroid follicular cell (thyrocyte); thyroglobulin. 


\section{Introduction}

Transport of di- and tripeptides into cells is mediated by members of the SoLute Carrier 15 (SLC15) $\mathrm{H}^{+} /$oligopeptide cotransporter family (Daniel and Kottra, 2004). To date, four peptide transporters have been cloned in mammals, namely PEPT1 (SLC15A1), PEPT2 (SLC15A2), PHT1 (SLC15A4) and PHT2 (SLC15A3). PEPT1 and PEPT2 have been characterized in great detail (Daniel and Kottra, 2004; Daniel et al., 2006; Rubio-Aliaga and Daniel, 2008). Both proteins utilize an inwardly-directed $\mathrm{H}^{+}$gradient to translocate di- and tripeptides across plasma membranes. They also transport a variety of pharmacologically important compounds such as $\beta$-lactam antibiotics, renin inhibitors, the aminopeptidase inhibitor bestatin, $\delta$-aminolevulinic acid and many selected pro-drugs (Brandsch et al., 2008; Rubio-Aliaga and Daniel, 2008). PEPT1 is a low-affinity/high-capacity transporter, mainly expressed in small intestinal epithelial cells and, to a smaller extent, in renal proximal tubular cells and bile duct epithelium. PEPT2 is a high-affinity/low-capacity transporter and is widely expressed within the organism; in particular, in renal proximal tubular cells and, at lower levels, in central and peripheral nervous system, lung, lactating mammary gland, spleen, pancreas, pituitary gland, testis, prostate, ovary, uterus and eye. PHT1 and PHT2 have been cloned from a rat brain cDNA library (Yamashita et al., 1997; Sakata et al., 2001) and recently PHT1 has also been cloned from the human placental trophoblast BeWo cell line (Bhardwaj et al., 2006). Information on transport properties, tissue distribution and subcellular localization of these transporters is very limited. Both proteins are capable of transporting the free amino acid L-histidine as well as selected di- and tripeptides in $\mathrm{a}^{+}$dependent manner (Yamashita et al., 1997; Sakata et al., 2001; Bhardwaj et al., 2006). PHT1 is abundantly expressed in brain, eye, lung, gastrointestinal tract and placenta (Yamashita et al., 1997; Herrera-Ruiz et al., 2001; Bhardwaj et al., 2006), while PHT2 is mainly expressed 
in lymphatic system, lung, spleen and thymus, and weakly in brain, liver, adrenal gland and heart (Sakata et al., 2001). Both proteins contain in their cytoplasmic domains di-leucine motifs related to sorting to endosomes and lysosomes (Yamashita et al., 1997; Sakata et al., 2001; Bhardwaj et al., 2006), and the rat PHT2 protein has been localized to the lysosomal membrane (Sakata et al., 2001). However, to date it is not clear whether the peptide/histidine transporters are located on the plasma membrane or represent lysosomal proteins.

Although expression of the SLC15 transporters has been studied in several tissues, little is known about their presence in thyroid. To our knowledge, information on expression in the thyroid is limited to a real-time reverse transcription-polymerase chain reaction (RT-PCR) assay in human tissue (Nishimura and Naito, 2005), while studies on functional transport of small peptides in epithelial thyroid cells are completely lacking. Nevertheless, it is of particular interest to study expression and function of peptide transporters in the thyroid as there a considerable turnover of proteins occurs. In fact, thyroid hormones production depends on cycles of synthesis and degradation of thyroglobulin (Tg) (Marinò and McCluskey, 2000; Brix et al., 2001) and SLC15 transporters in thyroid follicular cells could be involved in the transport of the small peptides derived from $\mathrm{Tg}$ synthesis/recycling processes.

We investigated whether and which peptide transporters are expressed in thyroid cells. More specifically, we characterized the transport function by using the fluorophore-conjugated dipeptide derivative $\beta$-Ala-Lys- $\mathrm{N}_{\varepsilon^{-}}$-7-amino-4-methyl-coumarin-3-acetic acid (Ala-LysAMCA) in both intact rat thyroid slices and rat thyroid PC Cl3 cells (Fusco et al., 1987), a thyroid epithelial (follicular) cell line (PC cell line clone 3) derived from 18-month old normal Fisher rat. Like other rat thyroid immortal untransformed cell lines (namely FRTL-5 and WRT cells), PC Cl3 cells retain many features of normal differentiated follicular thyroid cells, such as thyroid-stimulating hormone (TSH) dependence for growth and functions and 
$\mathrm{Na}^{+} / \mathrm{I}^{-}$symporter (NIS), Tg and thyroperoxidase (TPO) expression, and represent a valuable model to study thyroid cell function (for a comprehensive review on in vitro rat thyroid cell systems see: Medina and Santisteban, 2000; Kimura et al., 2001).

This study contains the first experimental evidence of functional expression of peptide transporters in follicular thyroid cells.

\section{Materials and Methods}

\subsection{Materials}

Calf serum, L-glutamine, penicillin/streptomycin and Coon's modified Ham's F12 culture medium (Coon's) were from Labtek Eurobio (Milan, Italy). Hydrocortisone, transferrin, Lglycyl-L-histidyl-L-lysine acetate and somatostatin were from ICN Biomedicals (Costa Mesa, CA). Sigma was the source for all the other chemicals.

\subsection{Animals}

Adult (150-200 g) Sprague-Dawley rats (Harlan Italia; S. Pietro al Natisone, Italy) were kept under standard laboratory conditions, with free access to standard laboratory food pellets and tap water. All experimental procedures were conducted according to the European Communities Council Directives (86/609/ECC), with all efforts to minimize animal sufferings and the number of animals necessary to collect reliable scientific data.

\subsection{Ex vivo uptake}


The thyroid of mice sacrificed by ether inhalation was removed and transferred to Coon's. Thyroid slices $(\sim 200 \mu \mathrm{m})$ were hand-cut using razor blades. Sections were incubated with

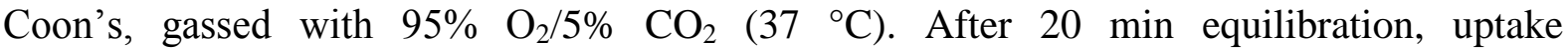
experiments were carried out by adding $25 \mu \mathrm{M}$ Ala-Lys-AMCA (final concentration) to the incubation medium. For competitive inhibition studies, $25 \mu \mathrm{M}$ Ala-Lys-AMCA plus $5 \mathrm{mM}$ carnosine ( $\beta$-alanyl-L-histidine) was used. Negative controls included the omission of fluorescent and competitor substrate. Incubations were stopped after 120 min by washing twice with ice-cold Coon's. The slices were fixed in 4\% paraformaldehyde, prepared in PBS (pH 7.4), for 30 min. Fixed tissues were rinsed in PBS and subsequently immersed in $18 \%$ sucrose-PBS solution for $20 \mathrm{~min}$. Tissues were removed from the sucrose solution, immersed in OCT cryo-embedding compound (Tissue-Tek, Milan, Italy), and frozen at $-80{ }^{\circ} \mathrm{C}$. After cryostat cutting to $18 \mu \mathrm{m}$ sections, the slides were examined with a Nikon Eclipse E800 fluorescence microscope (Nikon Corporation, Tokyo, Japan) using filter block UV-2A (bandpass filter 330-380 nm for excitation; long-pass filter $420 \mathrm{~nm}$ for emission).

\subsection{Cell culture}

PC Cl3 cells were grown in Coon's, supplemented with calf serum (5\%), L-glutamine (2 $\mathrm{mM})$, penicillin $(100 \mathrm{U} / \mathrm{ml})$, streptomycin $(100 \mathrm{ng} / \mathrm{ml})$ and a mixture of hormones and growth factors consisting of insulin $(1 \mu \mathrm{g} / \mathrm{ml})$, hydrocortisone $(3.62 \mu \mathrm{g} / \mathrm{ml})$, TSH $(1 \mathrm{mU} / \mathrm{ml})$, somatostatin $(10 \mathrm{ng} / \mathrm{ml})$, transferrin $(5 \mu \mathrm{g} / \mathrm{ml})$, L-glycyl-L-histidyl-L-lysine $(20 \mathrm{ng} / \mathrm{ml})$ (Fusco et al., 1987). The cells were maintained in a water-saturated atmosphere of $5 \% \mathrm{CO}_{2}$ and $95 \%$ air $\left(37^{\circ} \mathrm{C}\right)$. Cells were transferred to new plates every 3-5 days and the culture medium was changed every 2-3 days. Fresh medium was always added $24 \mathrm{~h}$ prior to an experiment. The cells were harvested with a $0.3 \%$ trypsin solution. 


\subsection{Uptake and fluorescence microscopy in PC Cl3 cells}

Transport studies with Ala-Lys-AMCA were performed as described (Dieck et al., 1999). Briefly, PC Cl3 cells were seeded on 24-well plates and used 1-2 days after plating (80-90\% confluence). After growth medium removal, the cells were washed twice in $1 \mathrm{ml}$ sodium medium (in mM: $137 \mathrm{NaCl}, 5.4 \mathrm{KCl}, 2.8 \mathrm{CaCl}_{2}, 1.2 \mathrm{MgSO}_{4}, 10$ HEPES, pH 7.4 with Tris; 37 $\left.{ }^{\circ} \mathrm{C}\right)$. Uptake was started by adding $0.5 \mathrm{ml}$ sodium medium containing Ala-Lys-AMCA at the indicated concentrations, prolonged for the indicated times, and terminated by removing the uptake medium and washing the cells thrice with ice-cold stop solution (in mM: $132 \mathrm{NaCl}, 14$ Tris, 5 carnosine; $\mathrm{pH} 7.4$ with $\mathrm{HCl}$ ). For $\mathrm{pH}$-dependence analysis, uptake experiments were performed as described above, but using sodium medium in which $\mathrm{pH}$ was adjusted at 5.4 or 6.4, with $10 \mathrm{mM}$ MES/Tris, or at 7.4 and 8.4, with $10 \mathrm{mM}$ HEPES/Tris. The cells were then dissolved with $0.5 \mathrm{ml} 0.5 \%$ Triton X-100. Uptake of Ala-Lys-AMCA was determined by measuring the cell-associated fluorescence (excitation, $350 \mathrm{~nm}$; emission, $455 \mathrm{~nm}$ ) using a Jasco FP-750 spectrofluorometer (Jasco Corporation; Tokyo, Japan). For each experiment a calibration curve was constructed. In particular, Ala-Lys-AMCA fluorescence was measured at increasing $(0-30 \mu \mathrm{M})$ Ala-Lys-AMCA concentrations in the presence of all the components of the lysis mixture, and the fluorescence data were plotted $v s$. the corresponding concentration data. Protein content was determined according to the Lowry method using BSA as standard. Fluorescence values were converted into pmol/mg protein (Fig. 2A) or $\mathrm{pmol} / \mathrm{min} \mathrm{x} \mathrm{mg}$ protein (Fig. 2B-D). Non-specific binding was determined as the residual fluorescence associated with the cells in the presence of excess $(5 \mathrm{mM})$ carnosine and subtracted from the total fluorescence values. 
For fluorescence microscopy studies, $\mathrm{PC} \mathrm{Cl3}$ cells were grown on cover slips inserted into 24-well plates. Transport experiments were performed as described above. The cells were incubated with $25 \mu \mathrm{M}$ Ala-Lys-AMCA or $25 \mu \mathrm{M}$ Ala-Lys-AMCA plus $5 \mathrm{mM}$ competitor (carnosine, glycyl-sarcosine or L-histidine). Negative controls included the omission of fluorescent and competitor substrate. After 90 min incubation $\left(37^{\circ} \mathrm{C}\right)$, the cells were washed thrice with ice-cold buffer and fixed with 3\% paraformaldehyde for 15 min at room temperature. The cover slips were then washed thrice with PBS (pH 7.4), transferred to slides, and embedded in mounting medium containing 1,4-diazabicyclo-(2,2,2)-octane (Sigma) for microscopic examination. Uptake of Ala-Lys-AMCA was assessed by fluorescence microscopy using a Nikon Eclipse E800 fluorescence microscope equipped with the appropriate filter combinations.

\section{6. $R T-P C R$}

Total RNA was isolated from $\mathrm{PC} \mathrm{Cl3}$ cells, rat thyroid and control tissues using TRIZOL Reagent (Invitrogen; Carlsbad, CA), and used (5 $\mu \mathrm{g})$ to perform RT with oligo(dT) ${ }_{12-18}$ and SuperScript III First-Strand Synthesis System for RT-PCR (Invitrogen). The resulting cDNA $(2 \mu \mathrm{l})$ was used to perform PCR with Platinum Taq DNA polymerase (Invitrogen) and primers as from rat sequences (Table 1). Primers for $\beta$-actin were used as an internal control. After a denaturing step at $94{ }^{\circ} \mathrm{C}$ for $2 \mathrm{~min}$, amplification was performed for 35 cycles of denaturation, annealing and extension, respectively, as follows: PEPT1, $94{ }^{\circ} \mathrm{C} / 40 \mathrm{~s}, 62{ }^{\circ} \mathrm{C} / 60$ s, $72{ }^{\circ} \mathrm{C} / 45$ s; PEPT2, $94{ }^{\circ} \mathrm{C} / 40$ s, $57{ }^{\circ} \mathrm{C} / 60$ s, $72{ }^{\circ} \mathrm{C} / 45$ s; PHT1, $94{ }^{\circ} \mathrm{C} / 40$ s, $58{ }^{\circ} \mathrm{C} / 60$ s, 72 ${ }^{\circ} \mathrm{C} / 90 \mathrm{~s} ; \mathrm{PHT} 2,94{ }^{\circ} \mathrm{C} / 40 \mathrm{~s}, 60{ }^{\circ} \mathrm{C} / 60 \mathrm{~s}, 72{ }^{\circ} \mathrm{C} / 45$ s. Final synthesis was always at $72{ }^{\circ} \mathrm{C}$ for 7 min. RT-PCR products were separated by electrophoresis on a $1 \%$ agarose gel and stained with ethidium bromide. Gel images were captured with Gel-Doc 2000 gel documentation 
system equipped with a CCD camera (Bio-Rad Laboratories, Hercules, CA). Their identity was confirmed by cloning and sequencing.

\subsection{Semiquantitative (relative-quantitative) $R T-P C R$}

Semiquantitative (relative-quantitative) RT-PCR analysis of SLC15 transcripts was performed using the Quantum RNA 18S internal standards system (Ambion Inc., Austin, TX). Briefly, total RNA was extracted from PC Cl3 cells grown in the presence or absence of TSH using TRIZOL Reagent. Five micrograms of total RNA were retro-transcribed using SuperScript III reverse transcriptase and random hexamers (Invitrogen) according to the manufacturer's protocol. Two microliters of the cDNA reaction mixture were used to perform duplex PCR with gene specific pairs of primers derived from rat sequences (Table 1) and primers for 18S rRNA (QuantumRNA Classic II 18S Internal Standards; product size 324 bp). To perform amplification under relative-quantitative conditions, preliminary experiments were carried out for each gene tested to determine the optimal cycle number and the appropriate ratios of $18 \mathrm{~S}$ primers and $18 \mathrm{~S}$ competimers according to the manufacturer's protocol. In particular, the $18 \mathrm{~S}$ primer:competimer ratio was 1:9 for PEPT1 and 2:8 for PEPT2, PHT1 and PHT2 genes. Relative-quantitative PCR amplifications were performed as follows: for PEPT1, $94{ }^{\circ} \mathrm{C} / 30 \mathrm{~s}, 57{ }^{\circ} \mathrm{C} / 30 \mathrm{~s}, 72{ }^{\circ} \mathrm{C} / 40 \mathrm{~s}\left(37\right.$ cycles); for PEPT2, $94{ }^{\circ} \mathrm{C} / 30 \mathrm{~s}$, $57{ }^{\circ} \mathrm{C} / 30 \mathrm{~s}, 72{ }^{\circ} \mathrm{C} / 45 \mathrm{~s}$ (35 cycles); for PHT1, $94^{\circ} \mathrm{C} / 30 \mathrm{~s}, 57{ }^{\circ} \mathrm{C} / 40 \mathrm{~s}, 72{ }^{\circ} \mathrm{C} / 50 \mathrm{~s}$ (37 cycles); for PHT2, $94{ }^{\circ} \mathrm{C} / 30 \mathrm{~s}, 62{ }^{\circ} \mathrm{C} / 30 \mathrm{~s}, 72{ }^{\circ} \mathrm{C} / 45 \mathrm{~s}$ (37 cycles). In all cases, final synthesis was performed at $72{ }^{\circ} \mathrm{C}$ for $7 \mathrm{~min}$. For each gene analyzed, the complete set of samples was assayed concomitantly using aliquots of the same PCR mixture and cDNA derived from individual samples. Each semiquantitative RT-PCR experiment was performed in triplicate. RT-PCR products were separated on a $2 \%$ agarose gel and stained with ethidium bromide. 
Gel images were captured and band intensities were quantified using the Quantity One 4.1.1 software (Bio-Rad Laboratories). To normalize gene expression, the gene-to-18S ratio was calculated, based on the quantification of the captured bands intensities. Relative gene expression was reported as the percentage of the gene-to-18S ratio calculated in the absence of TSH, to which an arbitrary value of $100 \%$ was assigned. The identity of each amplified RT-PCR product was verified by cloning and sequencing.

\subsection{Statistical analysis}

Data points are given as means \pm standard error. Within a single experiment, each point represents 3-4 replicate measurements. Each experiment was repeated at least 3 times. Statistical analysis was carried out using Student's $t$-test or one-way analysis of variance (ANOVA), as appropriate. When indicated, post-hoc test (Bonferroni) was also performed. All calculations were performed using Prism 4.0 (GraphPad; San Diego, CA).

\section{Results}

\subsection{Uptake of Ala-Lys-AMCA into rat thyroid slices}

Functional analysis of peptide transport in rat thyroid was performed on fresh tissue using Ala-Lys-AMCA as a reporter substrate. Incubation of thin rat thyroid slices with $25 \mu \mathrm{M}$ AlaLys-AMCA revealed uptake of the molecule and intracellular accumulation of fluorescence in the epithelial cells of the thyroid follicles (Fig. 1A). When uptake was performed in the presence of high concentrations $(5 \mathrm{mM})$ of carnosine, the fluorescence signals were reduced 
to a minimal extent (Fig. 1B). Control incubations with neither Ala-Lys-AMCA nor carnosine revealed completely unstained samples (Fig. 1C).

\subsection{Functional characterization of dipeptide uptake in PC Cl3 cells}

Ala-Lys-AMCA was used to analyze peptide transport in cultured $\mathrm{PC} \mathrm{Cl} 3$ cells. The time course of Ala-Lys-AMCA uptake was linear for $120 \mathrm{~min}$ (Fig. 2A) and was greatly diminished by an excess of carnosine, which suggested competition for a common transport system. Therefore, incubation times for all successive experiments were kept at $90 \mathrm{~min}$. AlaLys-AMCA transport as a function of Ala-Lys-AMCA concentration was a saturable process that followed Michaelis-Menten kinetics with a $\mathrm{K}_{\mathrm{m}}$ of $75.9 \pm 5.3 \mu \mathrm{M}$ and a $\mathrm{J}_{\max }$ of $5.0 \pm 0.17$ pmol/min x mg protein.(Fig. 2B). After Eadie-Hofstee transformation, a linear relationship was observed (Fig. 2C), indicating the occurrence of a single transport system. As expected, Ala-Lys-AMCA transport was $\mathrm{pH}$-dependent, with uptake increasing at more acidic extracellular pH (Fig. 2D).

Specific uptake of Ala-Lys-AMCA in $\mathrm{PC} \mathrm{Cl} 3$ cells was also assessed by fluorescence microscopy. Figure 3 shows representative bright-field and fluorescence images of cells incubated in a medium containing $25 \mu \mathrm{M}$ Ala-Lys-AMCA or $25 \mu \mathrm{M}$ Ala-Lys-AMCA plus 5 $\mathrm{mM}$ carnosine, glycyl-sarcosine or L-histidine. PC $\mathrm{Cl} 3$ cells displayed a bright blue fluorescence when incubated for 90 min with Ala-Lys-AMCA (Fig. 3B). Ala-Lys-AMCA uptake was inhibited by the concurrent application of either carnosine (Fig. 3C) or glycylsarcosine (Fig. 3D), which reduced cell-associated fluorescence to background levels. On the other hand, accumulation of Ala-Lys-AMCA was not reduced by L-histidine (Fig. 3E), a substrate of PHT1 and PHT2. Control experiments with neither Ala-Lys-AMCA nor competitors revealed completely unstained cells (Fig. 3F). 


\section{3. mRNA expression analysis of SLC15 transporters in rat thyroid and PC Cl3 cells}

Expression of SLC15 transporters putatively involved in the transport of di- and tripeptides in rat thyroid gland and $\mathrm{PC} \mathrm{Cl3}$ cells was analyzed by RT-PCR using rat-derived primer pairs specific for each SLC15 family member (Table 1). Representative data are summarized in Fig. 4. RNA from rat intestine, kidney, brain and spleen was used as positive control to test sensitivity of PEPT1, PEPT2, PHT1 and PHT2 primer pairs, respectively. RT-PCR revealed the presence of mRNA transcripts for PEPT2 as well as for PHT1 in both rat thyroid gland and $\mathrm{PC} \mathrm{Cl} 3$ cells (Fig. 4B and Fig. 4C). Furthermore, using rat PHT2-specific primers a faint amplification product was obtained from total RNA isolated from rat thyroid gland but not from PC Cl3 cells (Fig. 4D). PEPT1 mRNA expression was not detectable in both thyroid and $\mathrm{PC} \mathrm{Cl} 3$ cells (Fig. 4A). All amplification products were sub-cloned and sequenced to confirm their identity (data not shown).

\subsection{Effect of TSH on mRNA expression of SLC15 transporters in PC Cl3 cells}

Semiquantitative (relative-quantitative) RT-PCR analysis was performed to examine the expression of PEPT1, PEPT2, PHT1 and PHT2 mRNA in PC Cl3 cells grown for $48 \mathrm{~h}$ either in the absence of TSH $(0 \mathrm{mU} / \mathrm{ml})$ or in the presence of two increasing TSH $(0.1$ and 1 $\mathrm{mU} / \mathrm{ml}$ ) concentrations. A significant up-regulation of the mRNA levels of PEPT2 (one-way ANOVA/Bonferroni post-hoc test) was observed passing from cells incubated in the absence of TSH $($ reference value $=100 \%)$ to cells incubated with TSH $0.1 \mathrm{mU} / \mathrm{ml}(113.5 \pm 1.0 \% ; P<$ $0.001 ; n=3)$ and $1 \mathrm{mU} / \mathrm{ml}(128.8 \pm 1.1 \% ; P<0.001 ; n=3)$ (Fig. 5). No significant changes in PHT1 mRNA expression (one-way ANOVA/Bonferroni post-hoc test) were observed in 
both TSH $0.1 \mathrm{mU} / \mathrm{ml}(97.3 \pm 1.7 \% ; P>0.05 ; n=3)$ and $1 \mathrm{mU} / \mathrm{ml}(98.0 \pm 2.3 \% ; P>0.05 ; n$ $=3$ ) with respect to the absence of TSH (reference value $=100 \%$ ) (Fig. 5). On the other hand, PEPT1 and PHT2 mRNA signals were not detected in either the absence or the presence of TSH (Suppl. Fig. 1; see also Fig. 4).

\section{Discussion}

In this study we demonstrated the presence of specific mechanisms for peptide transport in thyroid follicular cells. Ala-Lys-AMCA was chosen as a reporter molecule to investigate peptide transport in rat thyroid tissue and cultured cells because it represents a good substrate for peptide transporters, with its high stability to enzymatic proteolysis, and allows direct visualization of peptide transport in both ex vivo and in vitro uptake experiments (Wenzel et al., 1998; Dieck et al., 1999; Groneberg et al., 2001; Groneberg et al., 2002a; Groneberg et al., 2002b; Groneberg et al., 2004; Rühl et al., 2005). Ex vivo, Ala-Lys-AMCA transport activity was directly localized in virtually all epithelial follicular cells of the rat thyroid gland. The specificity of Ala-Lys-AMCA uptake by these cell type was supported by the following evidences: 1) passive uptake of Ala-Lys-AMCA by diffusion was excluded by the lack of staining in non-follicular cells (e.g. C cells, accessory cells); 2) intracellular Ala-Lys-AMCA accumulation was competitively inhibited by high concentrations of carnosine, a typical substrate for SLC15 transporters. In agreement with the ex vivo experiments, peptide transport activity was demonstrated in $\mathrm{PC} \mathrm{Cl} 3$ cells, an in vitro model of rat thyroid follicular cells that retains many properties of the normally differentiated thyrocyte (Fusco et al., 1987). Ala-Lys-AMCA accumulation by PC Cl3 cells was mediated by a saturable transport system resembling the PEPT2-type transporter. This conclusion is supported by the following facts: 1) Ala-Lys-AMCA uptake occurred with high affinity, and the $K_{m}$ value was comparable to 
that reported for Ala-Lys-AMCA in rat glial cells, that endogenously express the highaffinity PEPT2 transporter (Dieck et a., 1999); 2) Ala-Lys-AMCA uptake in PC Cl3 cells was inhibited by carnosine, a typical substrate of SLC15 transporters, and by Gly-Sar, a specific substrate of PEPT1 and PEPT2 but not of PHT1 (Bhardwaj et al., 2006); 3) Ala-Lys-AMCA accumulation in PC Cl3 cells was not inhibited by L-histidine, a substrate for PHT1 and PHT2 (Yamashita et al., 1997; Sakata et al., 2001).

RT-PCR experiments confirmed expression of PEPT2 in PC Cl3 cells and demonstrated its physiological expression in rat thyroid gland. Interestingly, RT-PCR also revealed expression of mRNA for PHT1 in both thyroid gland and PC Cl3 cells. However, as described above, PHT1 did not seem to contribute to Ala-Lys-AMCA transport in PC Cl3 cells. This evidence would suggest intracellular localization of PHT1. In this respect, recent findings support the idea that PHT1, as well as PHT2, is localized in the lysosomal and/or early endosomal membranes (Sakata et al., 2001; Wada et al., 2005; Lee et al., 2009). However, because no data are available on the transport of Ala-Lys-AMCA by PHT1, we cannot exclude that PHT1 is expressed on the plasma membrane of $\mathrm{PC} \mathrm{Cl3}$ cells without participating to the uptake of the fluorescent substrate. In addition to PEPT2 and PHT1, RT-PCR has shown expression of PHT2 transcripts in rat thyroid gland but not in $\mathrm{PC} \mathrm{Cl} 3$ cells. This finding is not surprising given that PHT2 mRNA is predominantly expressed in the lymphatic system (Sakata et al., 2001) and that the thyroid gland is endowed with a rich intra-glandular lymphatic network (Ohtani and Ohtani, 2008).

TSH plays an important role in thyroid growth and differentiation, and several thyroid specific genes and differentiation markers (such as Tg, TPO, NIS and TSH receptor), thyroid specific transcription factors [such as Thyroid Transcription Factor 1 (TTF1), Thyroid Transcription Factor 2 (TTF2) and PAired boX gene 8 (PAX-8)] (for recent reviews, see e.g. Medina and Santisteban, 2000; Kimura et al., 2001), and, as recently assessed, amino acid 
transporters [such as Cationic Amino acid Transporter 1 (CAT-1), Cationic Amino acid Transporter 2B (CAT-2B) and the two heterodimeric amino acid transporters: 4F2 heavy chain/y ${ }^{+} \mathrm{L}$ Amino acid Transporter 1 (4F2hc/y ${ }^{+}$LAT1) and $b^{0,+}$ Amino acid Transporterrelated $/ \mathrm{b}^{0,+}$ Amino acid Transporter $\left.\left(\mathrm{rBAT} / \mathrm{b}^{0,+} \mathrm{AT}\right)\right]$ (Verri et al., 2005) are up-regulated by TSH. In the present study, we show that in PC Cl3 cells increasing TSH concentrations in the extracellular medium also results in a significant up-regulation of the mRNA levels of PEPT2, thus suggesting that this peptide transporter shares the same TSH hormonal control and/or physiological regulation with proteins highly relevant to thyroid cell physiology.

Overall, these data provide the first experimental evidence for functional and molecular expression of PEPT2 in the epithelial cells of thyroid follicles. In the thyroid gland, epithelial cells (thyrocytes) are organized as follicles delimiting a closed compartment, the follicular lumen. Thyrocytes produce large quantities of $\mathrm{Tg}$, the precursor of thyroid hormones, which is secreted into the lumen of the thyroid follicles and stored in a covalently cross-linked form. Release of thyroid hormones requires internalization of $\mathrm{Tg}$ by thyroid epithelial cells and successive proteolytic degradation within lysosomes (Marinò and McCluskey, 2000). Recently, it has been demonstrated that limited proteolysis of $\mathrm{Tg}$ at the surface of thyroid epithelial cells precedes its endocytosis. This process is mediated by secreted cysteine proteases (e.g. cathepsins B, K and L) and leads to the solubilization of the covalently crosslinked $\mathrm{Tg}$ and to the rapid liberation of thyroxine from the pro-hormone (Brix et al., 1996; Tepel et al., 2000; Brix et al., 2001; Friedrichs et al., 2003). According to this scenario, at the thyroid follicular level PEPT2 may be localized, as generally found in epithelia (Daniel and Kottra, 2004; Daniel et al., 2006; Rubio-Aliaga and Daniel, 2008), at the apical membrane of the thyrocyte where it could be involved in the uptake and recycling of peptide-bound amino acids derived from the extracellular Tg proteolysis occurring in the lumen of the thyroid follicles. 
In the last few years, two PEPT2-deficient mice lines have been generated by independent groups (Rubio-Aliaga et al., 2003; Shen et al., 2003). PEPT2 null-mice were healthy and displayed no obvious abnormalities in the kidney or brain. Our results point to the need to assess the effects of the PEPT2 deletion on thyroid functions and Tg metabolism.

Interestingly, in this study we provide indications that PHT1 transcripts are also expressed in thyroid follicular cells. Our results support the hypothesis (Sakata et al., 2001; Ocheltree et al., 2003; Wada et al., 2005; Bhardwaj et al., 2006; Lee et al., 2009) that PHT1 is located on the membrane of intracellular organelles, such as lysosomes and early endosomes. Although further studies are required to define the function of PHT1 in the thyroid epithelial cells, at least in theory this peptide/histidine transporter in the lysosomal membrane of thyrocytes could be important for the lysosome-to-cytosol release of short chain peptides as end products of Tg degradation.

In summary, this study represents the first description of the functional expression of PEPT2 in rat thyroid epithelial cells. PEPT2 could be relevant for removal/recycling of peptide fragments generated in the thyroid follicular lumen from the process of extracellular $\mathrm{Tg}$ proteolysis. 


\section{Acknowledgements}

This work was supported by grants from the University of Salento (Fondi ex-60\%, 20062008) and partly from the Apulian Region (Cod. Cip PS_070 and Cod. Cip PE_062). 


\section{References}

Bhardwaj, R.K., Herrera-Ruiz, D., Eltoukhy, N., Saad, M., Knipp, G.T., 2006. The functional evaluation of human peptide/histidine transporter 1 (hPHT1) in transiently transfected COS-7 cells. Eur. J. Pharm. Sci. 27, 533-542.

Brandsch, M., Knütter, I., Bosse-Doenecke, E., 2008. Pharmaceutical and pharmacological importance of peptide transporters. J. Pharm. Pharmacol. 60, 543-585.

Brix, K., Lemansky, P., Herzog, V., 1996. Evidence for extracellularly acting cathepsins mediating thyroid hormone liberation in thyroid epithelial cells. Endocrinology 137, 1963-1974.

Brix, K., Linke, M., Tepel, C., Herzog, V., 2001. Cysteine proteinases mediate extracellular prohormone processing in the thyroid. Biol. Chem. 382, 717-725.

Daniel, H., Kottra, G., 2004. The proton oligopeptide cotransporter family SLC15 in physiology and pharmacology. Pflügers Arch. 447, 610-618.

Daniel, H., Spanier, B., Kottra, G., Weitz, D., 2006. From bacteria to man: archaic protondependent peptide transporters at work. Physiology (Bethesda) 21, 93-102.

Dieck, S.T., Heuer, H., Ehrchen, J., Otto, C., Bauer, K., 1999. The peptide transporter PepT2 is expressed in rat brain and mediates the accumulation of the fluorescent dipeptide derivative beta-Ala-Lys-N-epsilon-AMCA in astrocytes. Glia 25, 10-20.

Friedrichs, B., Tepel, C., Reinheckel, T., Deussing, J., von Figura, K., Herzog, V., Peters, C., Saftig, P., Brix, K., 2003. Thyroid functions of mouse cathepsins B, K, and L. J. Clin. Invest. 111, 1733-1745.

Fusco, A., Berlingeri, M.T., Di Fiore, P.P., Portella, G., Grieco, M., Vecchio, G., 1987. Oneand two-step transformations of rat thyroid cells by retroviral oncogenes. Mol. Cell. Biol. 7, 3365-3370. 
Groneberg, D.A., Döring, F., Eynott, P.R., Fischer, A., Daniel, H., 2001. Intestinal peptide transport: ex vivo uptake studies and localization of peptide carrier PEPT1. Am. J. Physiol. Gastrointest. Liver. Physiol. 281, G697-G704.

Groneberg, D.A., Döring, F., Nickolaus, M., Daniel, H., Fischer, A., 2002a. Renal assimilation of short chain peptides: visualization of tubular peptide uptake. Pharm. Res. 19, 1209-1214.

Groneberg, D.A., Eynott, P.R., Döring, F., Dinh, Q.T., Oates, T., Barnes, P.J., Chung, K.F., Daniel, H., Fischer, A., 2002b. Distribution and function of the peptide transporter PEPT2 in normal and cystic fibrosis human lung. Thorax 57, 55-60.

Groneberg, D.A., Rubio-Aliaga, I., Nickolaus, M., Döring, F., Fischer, A., Daniel, H., 2004. Direct visualization of peptide uptake activity in the central nervous system of the rat. Neurosci. Lett. 364, 32-33.

Herrera-Ruiz, D., Wang, Q., Gudmundsson, O.S., Cook, T.J., Smith, R.L., Faria, T.N., Knipp, G.T., 2001. Spatial expression patterns of peptide transporters in the human and rat gastrointestinal tracts, Caco-2 in vitro cell culture model, and multiple human tissues. AAPS PharmSci. 3, E9.

Kimura, T., van Keymeulen, A., Goldstein, J., Fusco, A., Dumont, J.E., Roger, P.P., 2001. Regulation of thyroid cell proliferation by TSH and other factors: a critical evaluation of in vitro models. Endocrine Rev. 22, 631-656.

Lee, J., Tattoli, I., Wojtal, K.A., Vavricka, S.R., Philpott, D.J., Girardin, S.E., 2009. pHdependent internalization of muramyl peptides from early endosomes enables Nod1 and Nod2 signaling. J. Biol. Chem. 284, 23818-23829.

Marinò, M., McCluskey, R.T., 2000. Role of thyroglobulin endocytic pathways in the control of thyroid hormone release. Am. J. Physiol. Cell. Physiol. 279, C1295-C1306. 
Medina, D.L., Santisteban, P., 2000. Thyrotropin-dependent proliferation of in vitro rat thyroid cell systems. Eur. J. Endocrinol. 143, 161-178.

Nishimura, M., Naito, S., 2005. Tissue-specific mRNA expression profiles of human ATPbinding cassette and solute carrier transporter superfamilies. Drug Metab. Pharmacokinet. 20, 452-477.

Ocheltree, S.M., Keep, R.F., Shen, H., Yang, D., Hughes, B.A., Smith, D.E., 2003. Preliminary investigation into the expression of proton-coupled oligopeptide transporters in neural retina and retinal pigment epithelium (RPE): lack of functional activity in RPE plasma membranes. Pharm. Res. 20, 1364-1372.

Ohtani, O., Ohtani, Y., 2008. Organization and developmental aspects of lymphatic vessels. Arch. Histol. Cytol. 71, 1-22.

Rubio-Aliaga, I., Daniel, H., 2008. Peptide transporters and their roles in physiological processes and drug disposition. Xenobiotica 38, 1022-1042.

Rubio-Aliaga, I., Frey, I., Boll, M., Groneberg, D.A., Eichinger, H.M., Balling, R., Daniel, H., 2003. Targeted disruption of the peptide transporter Pept 2 gene in mice defines its physiological role in the kidney. Mol. Cell. Biol. 23, 3247-3252.

Rühl, A., Hoppe, S., Frey, I., Daniel, H., Schemann, M., 2005. Functional expression of the peptide transporter PEPT2 in the mammalian enteric nervous system. J. Comp. Neurol. 490, 1-11.

Sakata, K., Yamashita, T., Maeda, M., Moriyama, Y., Shimada, S., Tohyama, M., 2001. Cloning of a lymphatic peptide/histidine transporter. Biochem. J. 356, 53-60.

Shen, H., Smith, D.E., Keep, R.F., Xiang, J., Brosius, F.C. $3^{\text {rd }}$, 2003. Targeted disruption of the PEPT2 gene markedly reduces dipeptide uptake in choroid plexus. J. Biol. Chem. 278, 4786-4791. 
Tepel, C., Brömme, D., Herzog, V., Brix, K., 2000. Cathepsin K in thyroid epithelial cells: sequence, localization and possible function in extracellular proteolysis of thyroglobulin. J. Cell. Sci. 113, 4487-4498.

Verri, T., Dimitri, C., Treglia, S., Storelli, F., De Micheli, S., Ulianich, L., Vito, P., Marsigliante, S., Storelli, C., Di Jeso, B., 2005. Multiple pathways for cationic amino acid transport in rat thyroid epithelial cell line PC Cl3. Am. J. Physiol. Cell Physiol. 288, C290-C303.

Wada, M., Miyakawa, S., Shimada, A., Okada, N., Yamamoto, A., Fujita, T., 2005. Functional linkage of $\mathrm{H}+$ /peptide transporter PEPT2 and $\mathrm{Na}+\mathrm{H}+$ exchanger in primary cultures of astrocytes from mouse cerebral cortex. Brain Res. 1044, 33-41.

Wenzel, U., Diehl, D., Herget, M., Daniel, H., 1998. Endogenous expression of the renal high-affinity $\mathrm{H}^{+}$-peptide cotransporter in LLC-PK1 cells. Am. J. Physiol. 275, C1573C1579.

Yamashita, T., Shimada, S., Guo, W., Sato, K., Kohmura, E., Hayakawa, T., Takagi, T., Tohyama, M., 1997. Cloning and functional expression of a brain peptide/histidine transporter. J. Biol. Chem. 272, 10205-10211. 


\section{Figure legends}

Fig. 1. Ex vivo uptake of Ala-Lys-AMCA in rat thyroid gland. Incubation of thyroid slices with $25 \mu \mathrm{M}$ Ala-Lys-AMCA led to uptake and intracellular fluorescence (arrows) in thyroid gland epithelial cells (A). No uptake was observed in the presence of $5 \mathrm{mM}$ carnosine (B). Control without Ala-Lys-AMCA resulted in no fluorescent signals (C). Left, bright-field image; right, fluorescent image.

Fig. 2. (A) Time course of Ala-Lys-AMCA uptake in PC Cl3 cells. Cells were incubated for the time indicated with $25 \mu \mathrm{M}$ Ala-Lys-AMCA in the absence or presence of $5 \mathrm{mM}$ carnosine (** $P<0.01$ and $* * * ~ P<0.001$ by Student's $t$-test). (B) Kinetics of Ala-Lys-AMCA uptake by $\mathrm{PC} \mathrm{Cl3}$ cells. Ala-Lys-AMCA uptake was determined with 90 min incubations in sodium medium supplemented with 5-250 $\mu \mathrm{M}$ Ala-Lys-AMCA. The line represents the best curve fitting the data to the Michaelis-Menten equation and was obtained by an iterative non-linear regression program $\left(R^{2}=0.998\right)$. (C) Eadie-Hofstee plot of Ala-Lys-AMCA uptake data in B. The line represents the linear regression of the transformed data $\left(R^{2}=0.994\right)$. (D) $\mathrm{pH}$ dependence of Ala-Lys-AMCA uptake in PC Cl3 cells. Cells were incubated for $90 \mathrm{~min}$ in sodium medium supplemented with $150 \mu \mathrm{M}$ Ala-Lys-AMCA and buffered at pH 5.4, 6.4, 7.4 and 8.4. Different letters indicate significantly different values (one-way ANOVA; $P<0.05$ by Bonferroni post-hoc test).

Fig. 3. Effects of competitive substrates on Ala-Lys-AMCA uptake in $\mathrm{PC} \mathrm{Cl} 3$ cells. Incubation of cells with sodium medium containing $25 \mu \mathrm{M}$ Ala-Lys-AMCA led to uptake and consequent intracellular fluorescence accumulation (A, bright-field image; $\mathrm{B}$, fluorescent image). Ala-Lys-AMCA uptake was abolished by excess amount of carnosine (C) and Gly- 
Sar (D). L-histidine had no influence on Ala-Lys-AMCA uptake (E). No fluorescence was detected in the absence of Ala-Lys-AMCA (F).

Fig. 4. Detection of rat PEPT1, PEPT2, PHT1 and PHT2 mRNAs by RT-PCR in rat thyroid gland and PC Cl3 cells. RT-PCR was performed on total RNA from rat thyroid gland and PC $\mathrm{Cl} 3$ cells grown in complete culture medium using PEPT1 (A), PEPT2 (B), PHT1 (C) and PHT2 (D) specific primers. Total RNAs from rat intestine, kidney, brain and spleen were used as positive control for PEPT1, PEPT2, PHT1 and PHT2, respectively. $\beta$-actin-specific primers were used to generate an internal control in each sample. L, $1 \mathrm{~kb}$ plus DNA Ladder (Invitrogen); $\mathrm{H}_{2} \mathrm{O}$, no cDNA template in PCR reactions; +/- RT, presence or absence, respectively, of reverse transcriptase; Ctrl, control.

Fig. 5. Effect of thyroid-stimulating hormone (TSH) deprivation on mRNA levels of the PEPT2 and PHT1 genes in PC Cl3 cells. Relative-quantitative RT-PCR expression analysis was performed on total RNA extracted from PC Cl3 cells grown in complete culture medium either lacking TSH or containing TSH $0.1 \mathrm{mU} / \mathrm{ml}$ and $1 \mathrm{mU} / \mathrm{ml}$. 
Table 1. Primer sequences used for SLC15 transporters detection.

\begin{tabular}{llllll}
\hline Gene name Alias & RefSeq mRNA & Sense primer 5'-3' (Tm) & Antisense primer 5'-3' (Tm) & $\begin{array}{l}\text { PCR product size } \\
\text { (position on RefSeq mRNA) }\end{array}$ \\
\hline Slc15a1 & PEPT1 & NM_057121 & AGCTCTGATCGCAGACTCGTG $\left(54^{\circ} \mathrm{C}\right)$ & CTTTAGCCCAGTCCAGCCAGT $\left(55^{\circ} \mathrm{C}\right)$ & $591 \mathrm{bp}(260-850)$ \\
Slc15a2 & PEPT2 & NM_031672 & CTAGCGTGCTTGGCTTTTGCAG $\left(59^{\circ} \mathrm{C}\right)$ & CCTGTGACTGAGAACATGACC $\left(49^{\circ} \mathrm{C}\right)$ & $732 \mathrm{bp}(1337-2068)$ \\
Slc15a3 & PHT2 & NM_139341 & GAGTCTGGGTCACGGAGAC $\left(62^{\circ} \mathrm{C}\right)$ & GAGGCCCACGATGATGCTG $\left(62^{\circ} \mathrm{C}\right)$ & $739 \mathrm{bp}(47-785)$ \\
Slc15a4 & PHT1 & NM_144758 & GAGGGCCGTTCACAGAGGA $\left(62^{\circ} \mathrm{C}\right)$ & TGAGGCCTTATAGTCTGCAG $\left(62^{\circ} \mathrm{C}\right)$ & $859 \mathrm{bp}(931-1789)$ \\
Actb & $\beta$-act & NM_031144 & CGTGACATCAAGGAGAAGCT $\left(60^{\circ} \mathrm{C}\right)$ & ATCCACATCTGCTGGAAGGT $\left(60^{\circ} \mathrm{C}\right)$ & $444 \mathrm{bp}(708-1151)$ \\
\hline
\end{tabular}




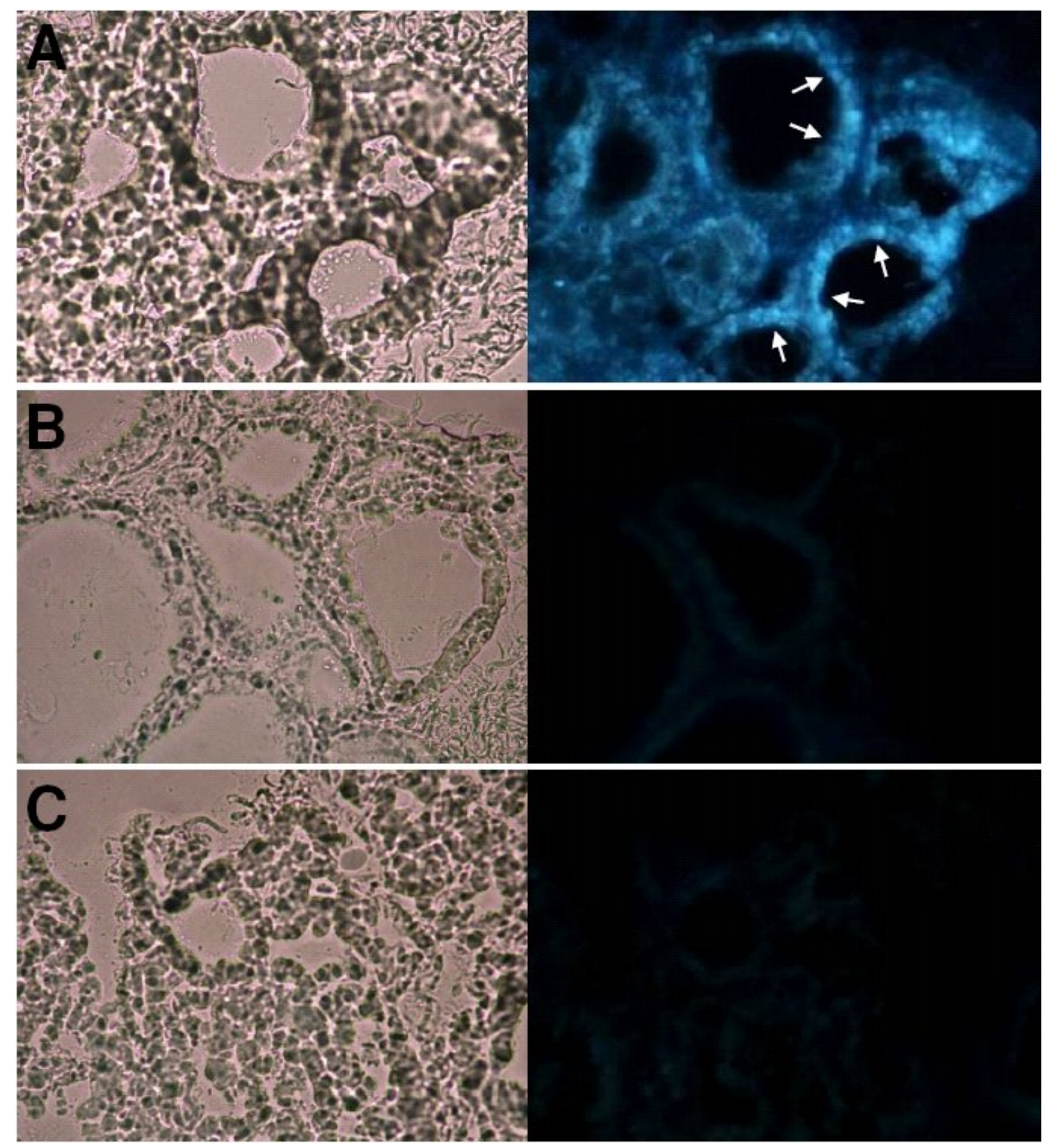

Fig. 1 


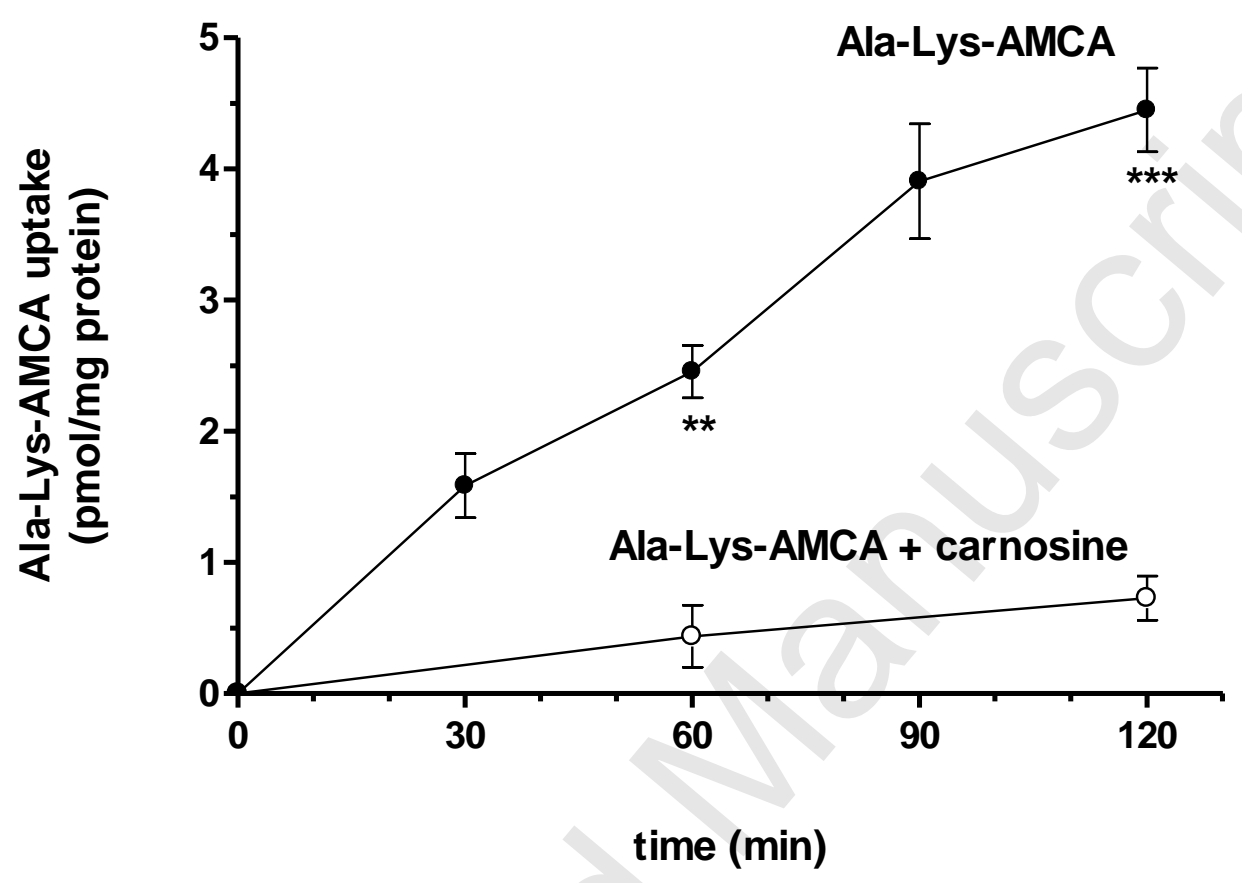

Fig. 2A 


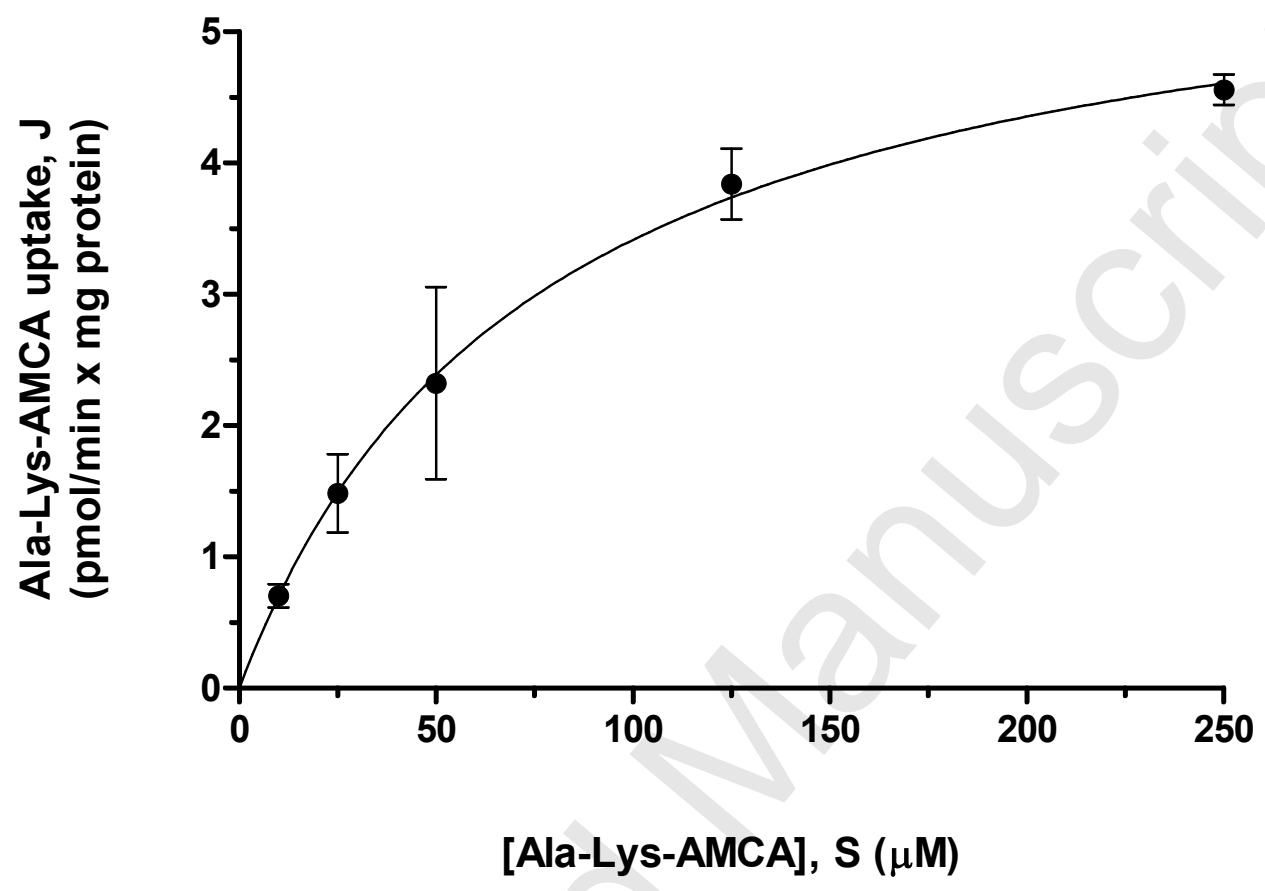

Fig. 2B 


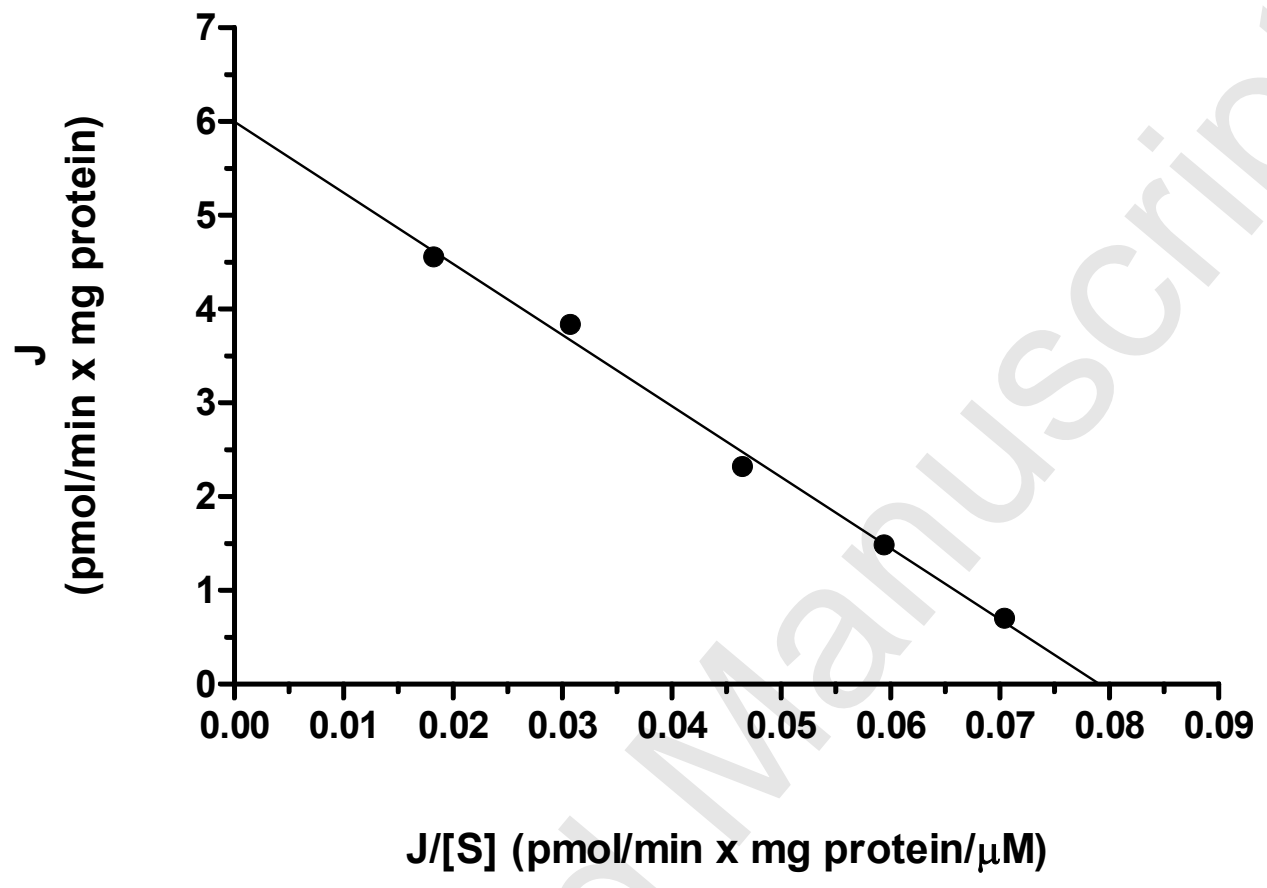

Fig. 2C 


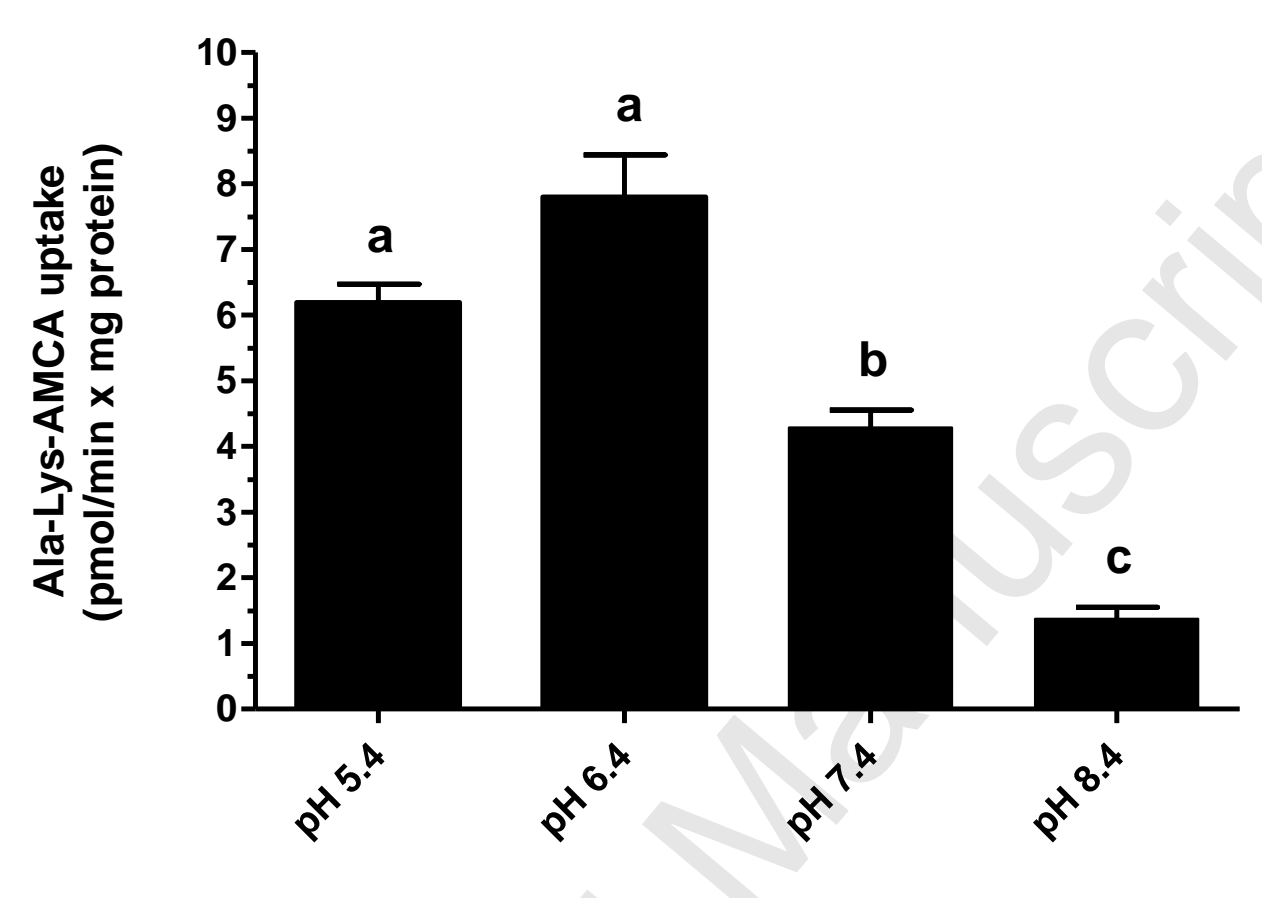

Fig. 2D

(r)



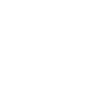

\author{
Fig.
}




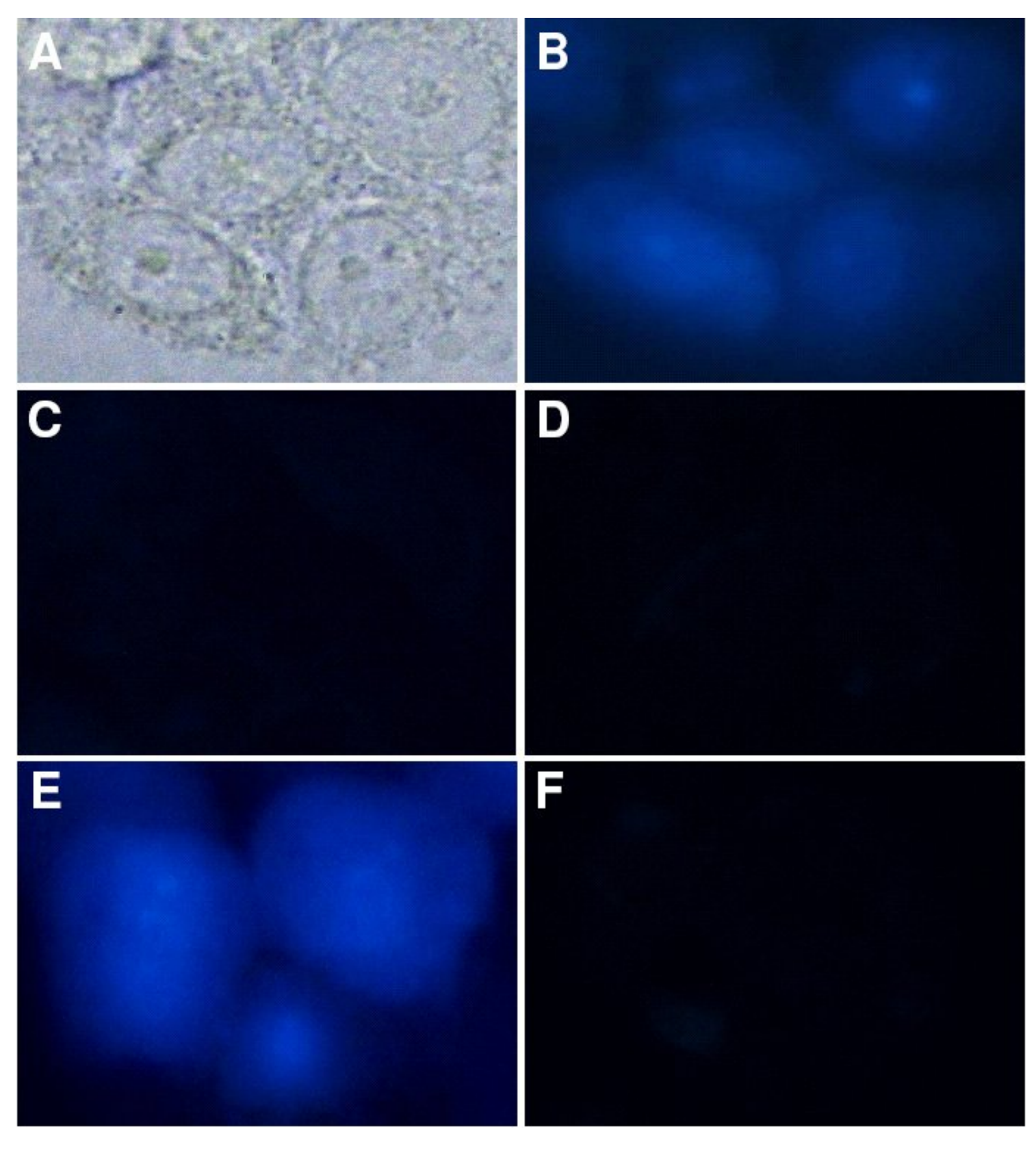

Fig. 3

\author{
ig. 3
}

(20)
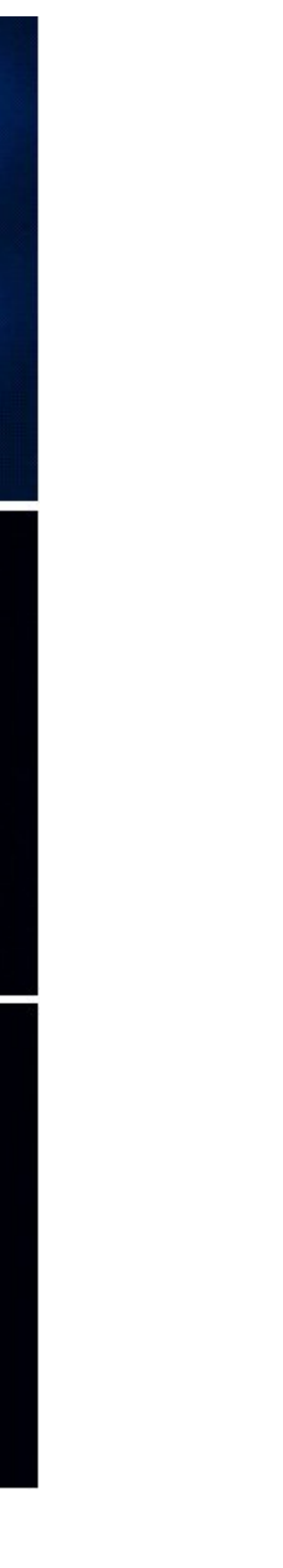


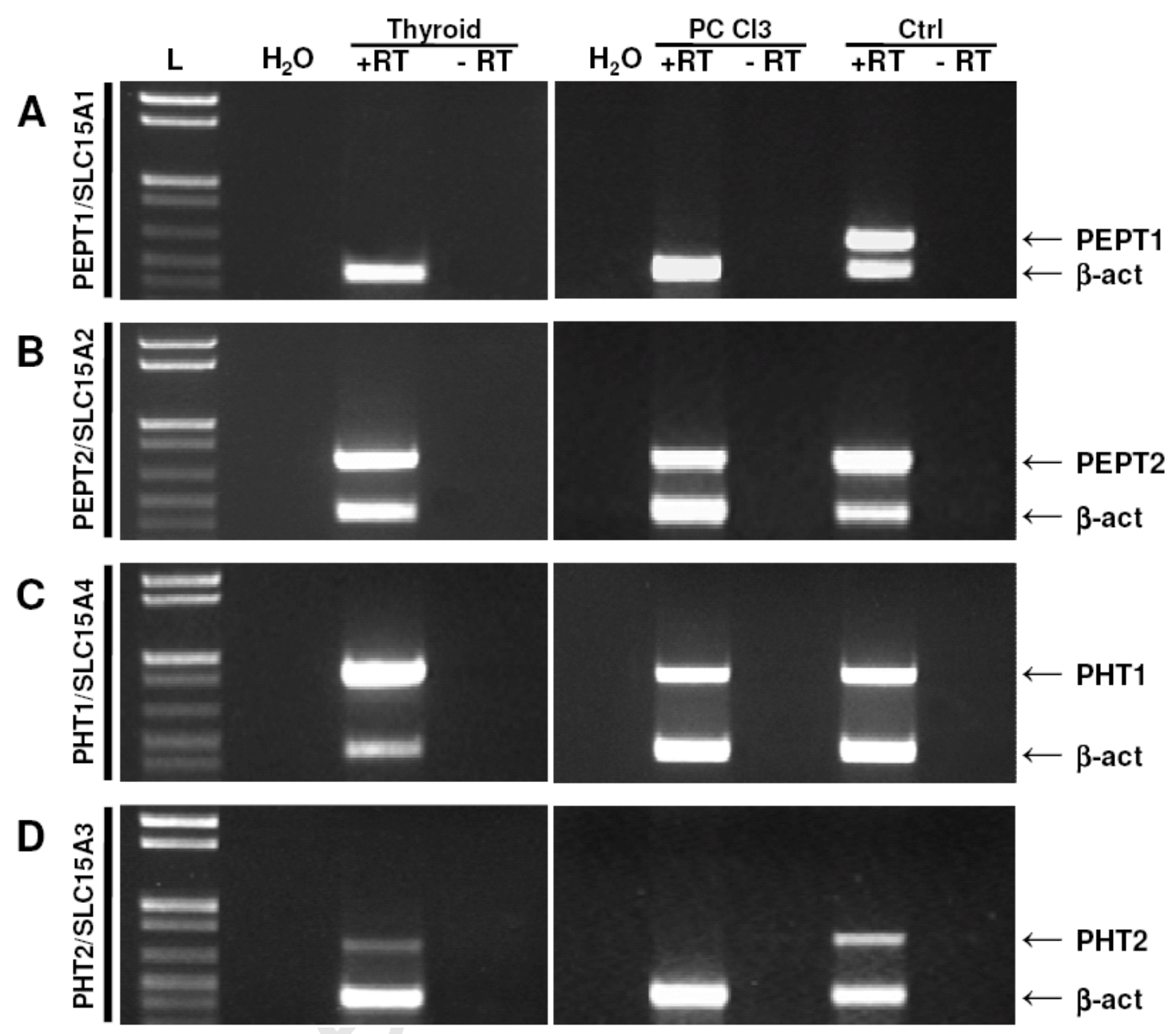

Fig. 4 


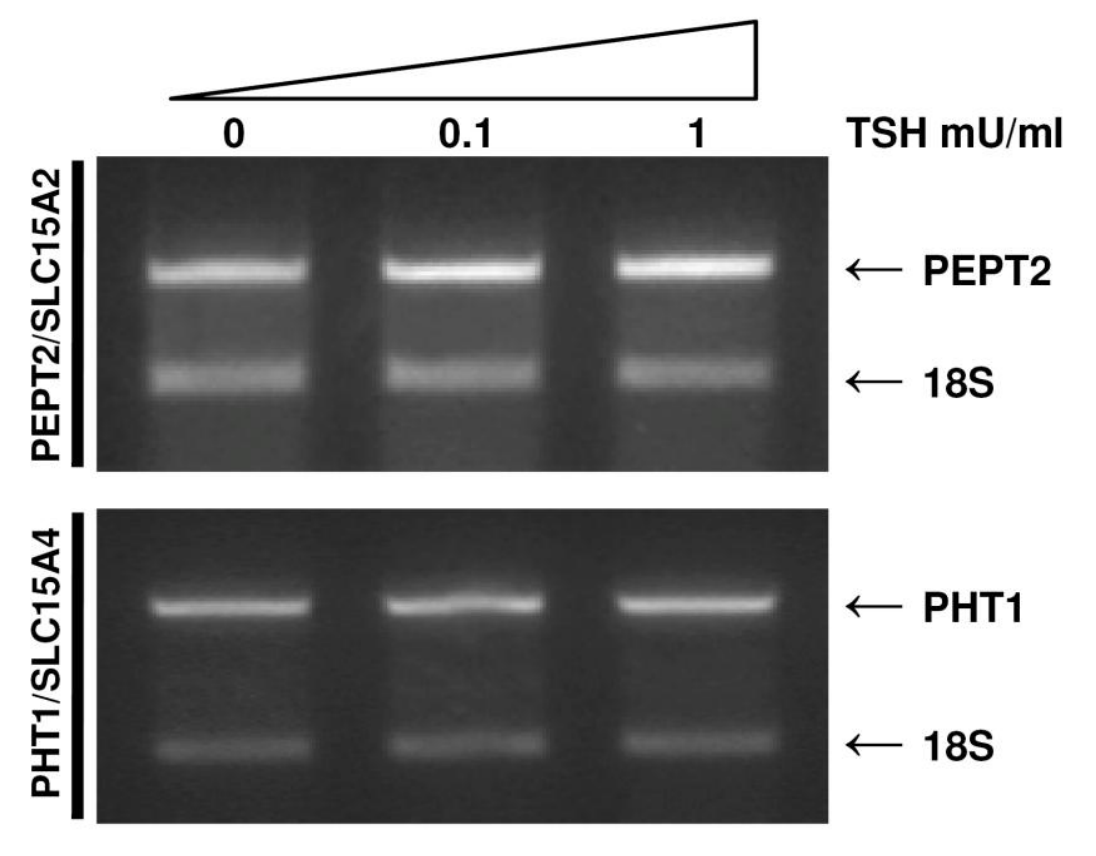

Fig. 5

aru

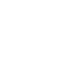

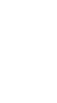

